\title{
CHOLESTEATOMA AND BONE DESTRUCTION
}

\author{
YUICHI SHIRAHATA, M. D. AND KEN SAITO, M. D. \\ Department of Otorhinolaryngology, The Jikei Univ. School of Medicine, Tokyo. \\ (Director: Y. Honda, M. D.)
}

\begin{abstract}
To clarify the mechanisms of born destruction in cholesteatomatous otitis media, a com parison of bone destruction of the ossicles removed during operation between chronic otitis media cases and cholesteatoma cases. Macroscopically the ossicular destruction was found in $93 \%$ of cholesteatomatous ears and $60 \%$ of chronic otitis media ears without choesteatoma.

Granulation or connective tissue was usually found microscopically in the bone defective area regardless to the pressure of cholesteatoma. In no case was stratified squamous epithelum found in a direct association with bone destruction. Inflammatory connective tissue was always interposed between the bone defect and cholestealoma. Therefore, stratified squamous epithelum by itself has probably no bone absorbing ability, but it is topographically forming a cyst or a non-cleansing pocket with secondary infection.

An infected "running ear" with or without cholesteatoma comprmises the ossicular integrity which is always requiring a special care.
\end{abstract}

A $82-0393-20131$

\section{真珠腫性中耳炎の骨破壊}

\section{第一報 組 織 学的検討上り}

\section{東京慈恵会医科大学耳犎咽喉科学教室（主任：本多芳男教授）}

白幡雄一, 斎藤建

はじめに

発生機転はなんであれ中耳真珠堙とは組織学的に角化 扁平上皮と上皮下結合織，肉芽組織上りなり，これが符

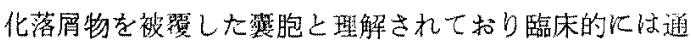
常 epithelial pocket を形成していることが公く認めら れている。

中耳真珠腄はそれと接する具壁を破塤し易く，多くの

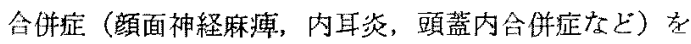
随伴しやすい，中耳真珠腫が危険視される理由はまさに その易骨破垻性化古り，そのためわれわれの多くの関心

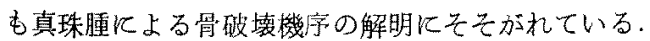

その真珠腫の病態儿ついては今なを明らかでない部分 が多く残されているが種々の研究手段の導入に上り，近
年多くの領域加らそれぞれのアプロー千がなされ，かな りの准歩が認められることは事実である。

私共は非真珠䐺性慢性中耳炎でむ骨破坮がみられるこ とにより，真珠胵と非真珠腫性中耳炎の骨破㙍性の差を 究明することが，真珠随炕よる骨跛壊機序をさくる一つ の手段になるろかと考无た，今回は慢性中耳炎で最も高 度で賎回な骨吸收がみられる耳小骨上，その周国飞存在 した上皮, 間葉組織肉腿的, 組織学的飞権祭し, 私共 の真珠腫による管破啾機序の研究の一端とした。

\section{対象亡方法}

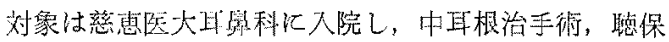
根治手術，鼓室成班術受け大175例（181耳）の慢性中 


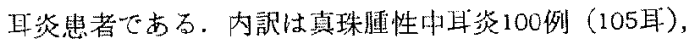

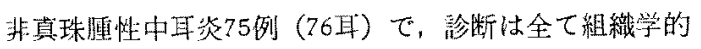
確定した，全粒例のうち35例（36耳）洅手術例であ る.

まず真跦腫中耳炎（以下真珠腫と略す）と非真珠腫性 中耳资（以下非真珠腫と略す）の術前熊力を初回手術例 飞限り $500 ， 1000,2000,4000 \mathrm{~Hz}$ で比較した. そして 患耳の術前耳漏の恃間的推移を調べ，手術に至るまでの 3力月間耳漏がみられなかった凯燥耳の場含を耳漏が長 期間なし，この期間耳漏が反復した場合を時々あり，継 綕して排亚していた場合を持続排朖とし真珠腫, 非真珠 腫例の各々で比較した。ついて手術時採取した病的耳小 骨の破垻度を部分破壊と完全破壊（消失）飞分け，真珠 腫と非真珠蹗にみられる割合を各耳小骨每汇比較した。

手術時標本は主飞上皮, 上皮下結合織, 肉芽組織, 耳 小骨でここれら10\%ホルマリン固定され，プランク

リ于ュル法で迎速脱灭した後，アルコール・キシロー ル䒺列で透徽し，バラフィン包埋した，染色はへマトキ シリンエオジン染色在基本とし，好銀楾䧽染色，マッ ソントリクロール染色, PAS 染色, アルンアン・ブ ル一染色，トルイジン青火よるィタクロマジ一法存施し た. また一部形質細胞の染色に秀れているメチルグリン ピロニン染色を使用した。亦た49歳，男性（交通事故で 死亡，4㭙間経過）の正常耳小骨を組織学的に観察し， 病的耳小骨と比轒するための基礎資料とした.

手術時採取された組織標本は標本作製時既亿軟部組織 と县吕分離していたものや，真珠腫上皮が既儿消失して いた不良標本加ら，耳小骨欠損のある部位に角化肁平上 皮や肉芽組織あるいは涷な結合織吕付着していた良性㥀 本まで区ヶであった。

組織学的检討の対象となり得た破塤耳小骨を有する組 織標本は真珠缰76耳，非真珠隀37耳であった。まず破骨 縁化接する閒集織のうっ血, 細胞浸潤度を調べ，肉芽を 单純性资芽(新生毛細血管と線維芽細胞を主体とする幼 若な結合織)，腺梯構造を有する肉芽，ヒヨレステリン結 晶がみられる肉芽化分類し観祭した，骨病变はVascular

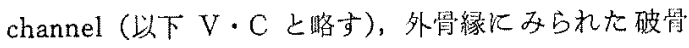
性病変・造骨性变化を主体K，V・C のうっ血・細胞浸 潤の割合, 拡張の具合, 肉芽組織, 血栓の有然, 督細胞 の変性，壊死の度台を調でた。また破骨緑周辺にみられ た組織上の特徽ある病変は，特㷠染色を施した上光学鼲 微鏿下に詳細に観察した。

\section{成綪}

A, 臨床的熦察

1. 初回手術時組織埰取され, 病理組織学的検討の行わ れた真珠腫61例中57例 $(93 \%)$ ，非真珠腫30例中18例(60 \%)飞正小骨破壤がみられた。破壊耳小骨は真珠連，非

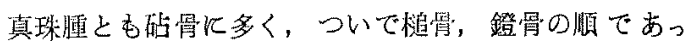

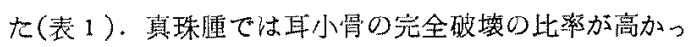
たが，これらの事実峘真珠腫では骨病变がより高度て類 回であったことを示している，耳小骨の久提部位社従来 から多く言われている様化耳小骨の解㜨学的位置関係， 栄養血管の分布様式汇むとずき，肉芽保露出されやすい 砧骨長脚・体部，槌骨頭部，鐙監頭・脚部に多くみられ た．胃完全融解が鐙骨(プレートは残っている場合が王 倒的に多い）に多くみられたのは，鐙骨は鼓室底に位置 し，炎症が強い場合には豊富な肉芽の中に埋もれ，血流 の悪い鐙骨頭部・朋部が学填死飞陷り吸収・排除を受け るためであるう。

2. 慢性中耳㷋の病態は主病变の存在部位より, 耳管鼓 室型と上鼓室型汇大别され，後者はしばしば真珠腫性中 耳炎といった病態を示している。しかし中耳炎病態の如

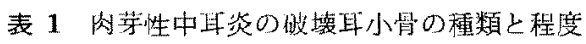
(初回手術咧)

\begin{tabular}{|c|c|c|c|c|c|c|}
\hline & \multicolumn{3}{|c|}{ 非真珠缰18例 } & \multicolumn{3}{|c|}{ 真珠腫57例 } \\
\hline & 随骨 & 砧骨 & 鐙監 & 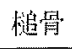 & 砧筲 & 蹬南 \\
\hline 部分破壊 & 10 & 16 & 0 & 26 & 35 & 10 \\
\hline \multirow[t]{4}{*}{ 完全破境 } & 0 & 2 & 5 & 11 & 16 & 16 \\
\hline & 10 & 18 & 5 & 37 & 51 & 26 \\
\hline & & & & & & \\
\hline & & 表 & 2 & & & \\
\hline
\end{tabular}

\section{真珠腫と非真珠腫の聴力}
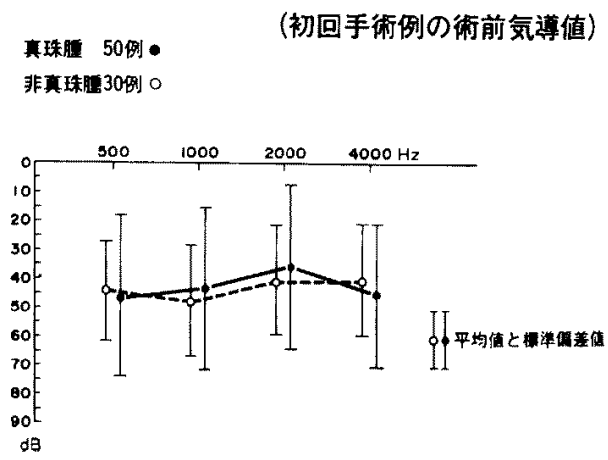
何を問わず中耳腔の炎性病变により中耳伝音系のインピ ーダンス整合は障害され, 気導聴力閾值の上早がみられ る. その聴敩閾值は大かたの中耳腔病変の強弱の程度を 表わす機能的示標である.

真珠腫52例, 非真珠腫30例（全て初回手術例）の術前 聴力検查の結果を表 2 飞示した. この病態を違える2つ の中耳炎の聴力像は類似し, 統計学上の有意差はない. このことは耳小骨に及ぼす影響が同程度であるというよ り，真珠腫ではマトリックスが破壊耳小骨に介在した結 果，その代用を果たし聴力は見かけ上保たれているもの と解釈した.

3. 術前の 3 力月間, 真珠腫例では65\%に持続排膿がみ られ, 手術時乾燥耳にあったものが $5 \%$ だあったのに比 し, 非真珠腫例では12\%に持続排膿があり, 39\%に時々 排膿が認められ，49\%は長期間にわたり患耳は乾燥した 状態にあった.この事実は真珠腫での保存的治療の難か しさを表わしている(表 3 ).

B, 組織学的観察

1. 真珠腫, 非真珠腫を問わず, 破骨縁に軟部組織の附 着ある場合には局面に接して全例に肉芽や疎な結合織が 存在していた. 弱拡大で一見角化㳮平上皮が骨吸収面を 被うように見えた場合（図 1) でも, 強拡大にすると上 皮と破骨縁との間には常に間尜があり, 結合織が介在し ていた（図 2 ）。この所見は 銀線維染色でみると一層明 瞭であった。

2. 破骨縁にみられた上皮下固有層は線維芽細胞, 毛血 管を主とした肉芽組織からなることが多く, 間葉組織に は好中球, リンパ球, 形質細胞を中心とした小円形細胞 浸潤之細血管の㹡張, 血腫形成, 腺様構造ないし垶胞の 形成がみられ，それぞれの炎症時期に㥵灾した特徵ある

表 3

\section{術前の耳漏}

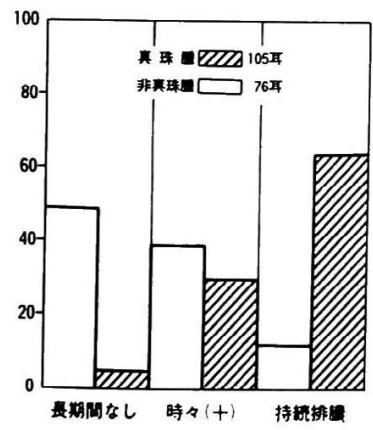

耳漏中の細菌

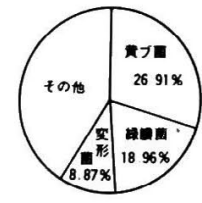

$4-51$

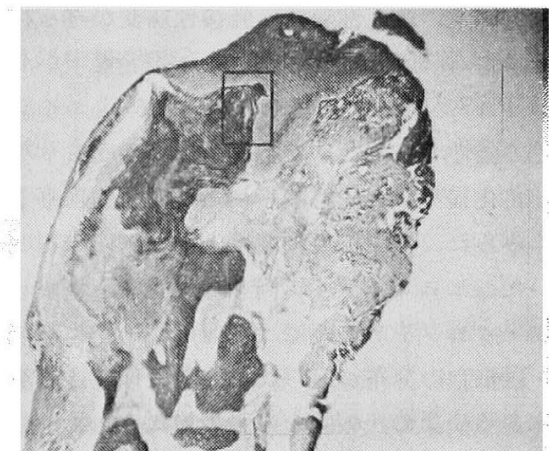

図 1

弱挔大, 砧骨, 好銀線維染色上皮下固有層 に延びた上皮突起が一部骨面を覆っている様に みえる。

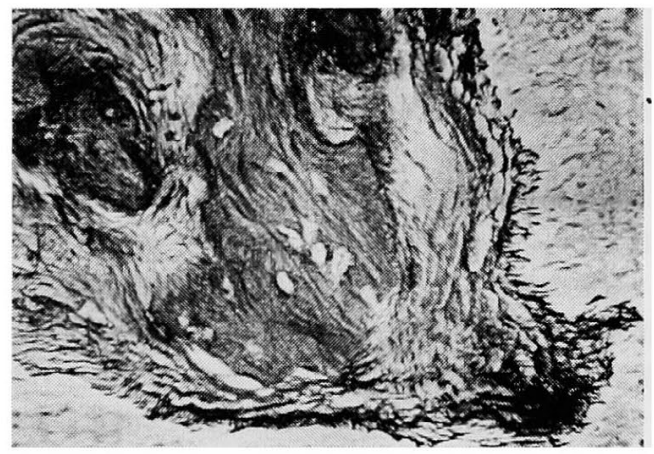

図 2

図 1 の強抎大, 上皮の底層と骨面との間には 結合織線維が錹走している。

表 4 骨破壊ある真珠腫と非真珠腫の肉芽の性状

\begin{tabular}{|c|c|c|}
\hline & 真珠腫 75 耳 & 非真珠腫34耳 \\
\hline ろっ血・細胞浸潤 & $78 \%$ & $75 \%$ \\
\hline 肉芽 組 織 & & \\
\hline 単純 & $88 \%$ & $80 \%$ \\
\hline 腺＼cjkstart様＼cjkstart構＼cjkstart造 & $15 \%$ & $15 \%$ \\
\hline ヒョレステリン肉芽 & $22 \%$ & $13 \%$ \\
\hline V.C の 病 変 & & \\
\hline ろっ血・細胞浸潤 & $38 \%$ & $48 \%$ \\
\hline 肉 芽 組 織 & $43 \%$ & $32 \%$ \\
\hline 血 栓 & $0.8 \%$ & $12 \%$ \\
\hline
\end{tabular}


退行性病变, 反応性病変, 修復性病変がみられた。褧胞 の 形成は腺様構造が 豊富である程 発現率が高く, 内容 物は PAS, アルシャンブルー拉びトルイジンブルー

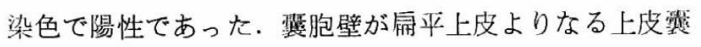

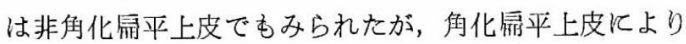
多くみられ，その発現頻度は上皮性病变の程度飞比例し ていた．ヒヨレステリン肉芽も稀にみられ，ヒヨレステ リン・クレフトの周囲には赤血球, へモジデリンの沈 着, 巨細胞の分布がみられた. 白血球遊走と集䅡は急性 期飞ある病巣の比較的上皮下浅層にみられ，リンパ球， 形質細胞の出現は非特異性增殖性慢性炎症の結果と思わ れた (図3).

以上の 变化は真珠腫飞特徽的飞みられた病变ではな く, 非真珠腫でも同様飞みられ(表 4), 更飞骨破壊を伴 わない慢性中耳炎の资症性肉芽組織とも本質的飞類似し ていた.

3. 破骨縁にみられた上皮下固有層結合織ないし肉芽の 性状は線維芽細胞, 線維芽細胞より産生された線維成分 （主飞膠原線維）の増生, その線維束が 錯走する間に 長 い突起をもち棈円形を呈する組織球様の大単核細胞の集 合，毛細血管が主であった（図4). しかしこの性状も 非特異的肉芽組織の螌囲を逸脱するものではなかった。

4. 骨破壊あるところの骨吸収窩には, 骨面飞向加って 垂直様に配列する細線維（主に膠原線維）があり，一見 骨基質を構成する線維がほぐれて骨基質外飞放出された ような像がみられた．その不規則に乱れた細線維にまつ わるように組織球様細胞が散在していた. はっきりと破

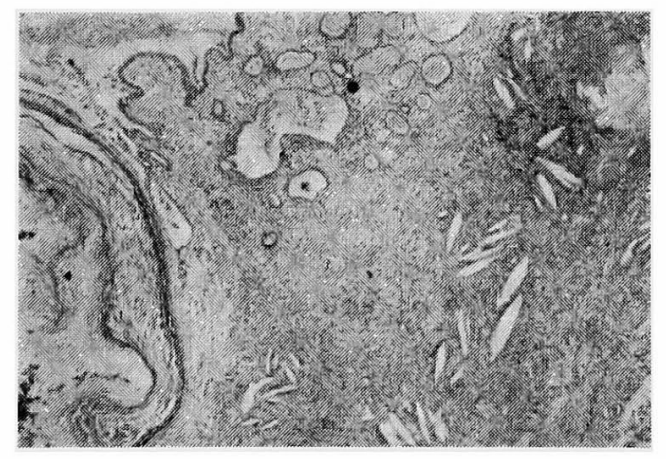

図 3

弱拡大, $\mathrm{HE}$ 染色, 真珠腫, 例円柱上皮莡覆 うように角化重層扁平上皮の進展がみられる。 上皮下固有層には腺翼胞, ヒョレステリン結晶 を囲む様に肉芽の増生がみられる。

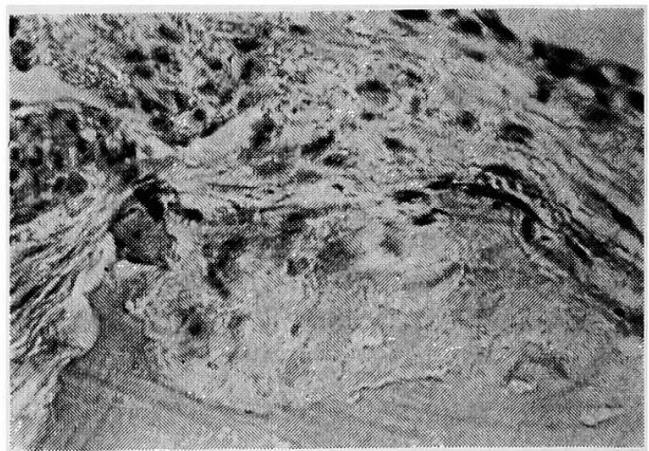

図 4

強挔大, $\mathrm{HE}$ 染色, 真珠腫例 破骨縁火は組 織球様細胞の集合がみられる.

骨細胞といえる様な多核巨細胞は骨外層の吸収窝には認 められなかった。

5. 破骨縁は鋸歯状を呈し，その一つ一つは虫食い像様 にみえた．破壊が進み大きく骨欠損を示す部位は，その 周囲の拡大した $\mathrm{V} ・ \mathrm{C}$ と融合して骨面飞深い陥みを作っ ていた．類骨組織は破骨縁に隣接してみられ，その一部 には部分的な石灰沈着があり, 骨吸収の一方では盛しに 骨新生が行われていることを示していた．類骨組織のあ る部は PAS, アルシアンブルー, トルイジンブルーに 陽性であったので石灰化の過程にはグリコーゲンがある 種の役割に参加すると考えられた．骨破壊の強くみられ た骨面飞は，発育旺盛な肉芽飞囲まれ壊死飞陥入った骨 組織むみられ，それが骨母体より遊離して領食されてい る様な所見もみれた.

6. 細胞浸潤, ろっ血が V・C 亿みられ慢性骨髄炎像飞 匹敵する所見を呈したものも, 真珠腫, 非真珠腫伴同程度 そみられた. 細胞浸潤は肥厚した血管周曲飞密集し局在 している傾向があった. 肉芽で閉塞されたり, 血栓を形 成していた V・C あみられた。これらの変化とより V・ Cはしばしば拡張し歪められていた（図 5 ).

7. V・C Kみられた骨吸収窝飞も，骨外層にみられた と京様な細線維のほぐれ, 組織球様細胞, 細血管の增生, 幼若な結合織細胞, 膠原線維の増生がみられた。破骨細 胞は Howship's lacunae 中に散見されたが, 破骨細胞 の近傍には特に組織球様細胞が目立った. 破骨縁の周辺 では一層の厚みで骨芽細胞が出現している様な骨新生像 ああり，部分的には骨が硬化しているところもあった。 新生した骨はエオジン飞浱染し, 骨変性が強い場合飞は 骨の染色性は悪くエオジンは淡くなっている場合が多か 


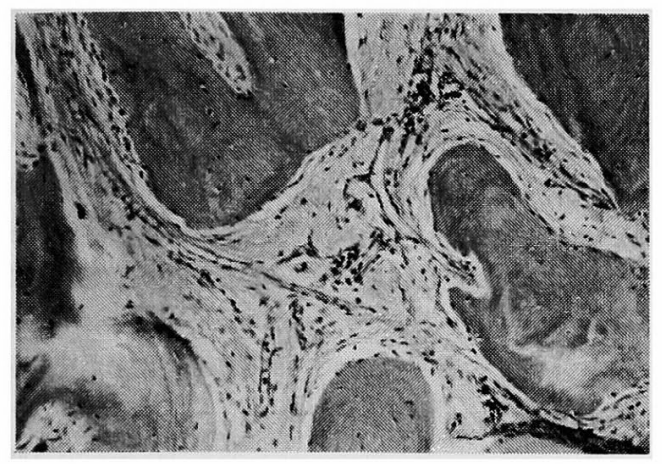

図 5

中等挔大, $\mathrm{HE}$ 染色, 真珠腫例 拡張した V.C 飞毛細血管の豊富な肉芽がみられる。

った，それ故骨の新生，吸収の様相は不規則で，複雑な 敘理を呈していた.

8. 角化落首物飞埋もれたり， $\mathrm{V} ・ \mathrm{C}$ の中にまで侵入し た真菌塊，あるいは上皮と置換するごとくその上皮束の 全長に亘って真菌の増殖を認めることがあった（図6). これらの菌要素は H・E染色，およびワンギーソン染色 では濃褐色飞み光, PAS 染色では褐紅色, アルシアン ブルー, トルイジン青染色に染まった，真菌による感染 は真珠腫で明らかに多い傾向を示していた.

9.上皮下固有層の一部の線維（膠原線維, 細網線維) は小血管とともに Volkmann 管を通じ 内部骨構造と入 り，ハーバー氏管や Howship's lacunae と直接連絡し ていた.この結合織が侵入し易い部位は，骨破壊ないし 变性をきたした部位で, 骨細胞は空胞化ないし濃縮化な どの壊死傾向が強く，大部分の骨小腔は筀胞化してお

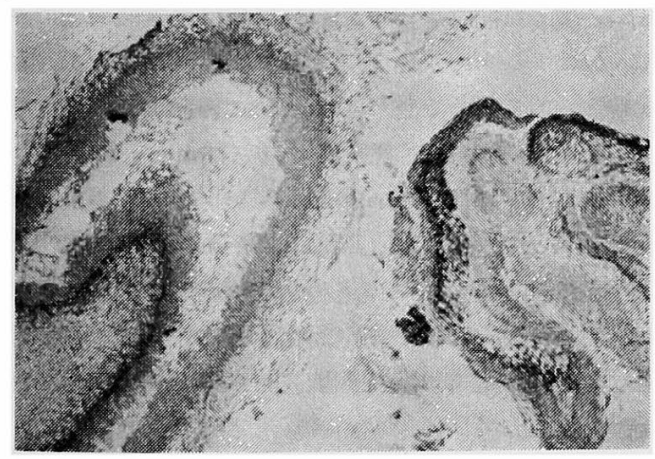

図 6

弱㹡大, $\mathrm{HE}$ 染色, 真珠腫例上皮束の全 長に亘り真菌の増殖がみられる.
り，骨梁は变形して異常な紋理を呈していた．これらの 肖細胞成分の広箸な破壊は真珠腫で特に真珠腫上皮が接 近する部位の骨表面に目立った。一方, 非真珠腫では骨 表面が高度に破壊されたものは少く，骨の新生による修 復が随所飞みられたのが僅かな特徽であった。

\section{考按}

占来慢性中耳炎の，永飞真珠腫性中耳炎の骨破壊機序 について解説した報告は枚挙にいとまがない。それは骨 破壊が真珠腫性中耳炎の特徵ある病变と考えられてきた からである.しかし、真珠腫, 非真珠腫とも炎症を基盤 にした病態であること变りはなく, 肉眼的にも, また 組織学的にも骨破壊は真珠腫に限らず非真珠腫にもみら れた.

もし真珠腫が特異的な骨破壊能をもっているとした ら, それは組織学的飞真珠腫を特徵つけている角化扁 平上皮の骨破壊能と換言できるであろうか.しかし私 共の手術時標本の組織学的観察では上皮が直 接 破 骨 縁 に接していた症例は一例もなかった，真珠腫の存在を問 わず骨破壊のみられた周辺には, 上皮と破骨面との間に 肉芽や結合組織が必ず介在していた，この結合織は真珠 腫露の拡張による圧迫刺激により 2 次的に生じた反応性 増殖組織との考えもできようが，採取した切片の中には 直接上皮が骨に接しているすのは 1 例みられなかったこ とは, 真珠腫上皮が直接骨破液を惹起するといった見方 に疑問をいだかせるものである。

私共の慢性炎症中耳腔粘膜, 骨組織の肉眼的, 組織学 的観察によれば真珠腫では非真珠腫より耳小骨の破壊が 多くみられ，かつ破壊が高度であった.

このように真珠腫でより高度で頻回な骨病変がみられ た理由の一つは, 真珠腫と非真珠腫の局在部位の運いに よるものと考えられないだろろか.つまり上鼓室型慢性 中耳炎の大部分が真珠腫であったことより, 上鼓室の大 部分を占める耳小骨の影響は重大であると考える.

ところで私共の観察によれば真珠腫, 非真珠腫とも組 織学的にみて耳小骨病变飞量的は差はあっても質的な差 異はほとんどみられなかった、この事実は骨破壊をさた す原因が肉芽側にあることを想像させる.耳小骨の欠損 部位には肉芽の付着をみることが多く, その場合肉芽の 増生は栄養血管の走向と一致していることが多かった. 従って鼓室腔炎症に基く肉芽の形成は真珠腫と非真珠腫 との病態差というより, 豊血管野での血管炎, 血管周囲 炎の帰結と考えられた，真珠腫では非真珠腫に比してよ 


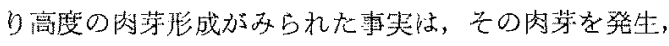

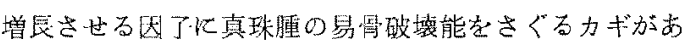
ることを考えさせる，貸珠霾は通常 Epithelal pocket を形成しているため，ま大真珠堙が介在する部位には

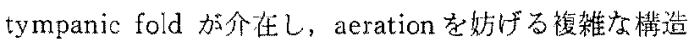
があるため，機械的な自看作用に之しく炎症が僄延し易

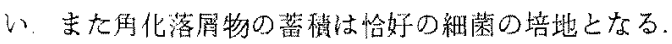
それ故真珠腫は乾燥し奞く，活動性の炎症を伴うことが 多い上思われるのだが，一般に裴皮の性格としてむる期

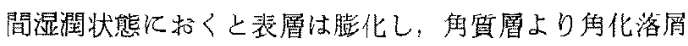

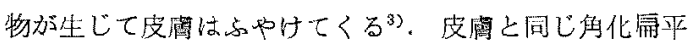
上皮よりなる真珠腫でも，wetな状態では落屑物の蓄䄸 は一層著明となるう：その重皘した角化落居物怙異物と して境死飞陷入り断裂した上皮束間より，器質化機轱に 上り肉荡の增殖を一層促むことになると思われる。

では肉芽が骨破壊上一元的なか力わりあいをもってい るとしたら，その肉芽の性状飞特徵はないであるうか， 悡共の観察に上れば，真珠腫でも非真珠腫でも上皮下固 有膡にみられた組織学的变化は本質的に同しであった。 その組織学的所見の要約は結合織の增生が病变の主作を

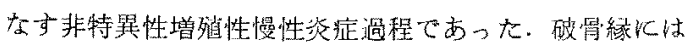
血管の增生が一層著明で，末䰻な線維芽細胞事数を増

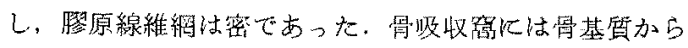
線維が汪ぐれ放散したような緗線維输がみられ，之心線 維間には組織球様細胞が比較的多くみられた。骨泺組 胞や稀儿破骨細胞屯骨破填の程度儿応してみられ，骨 の吸收のある一方では骨の新生が行われていることを如 类に示していた。

炎症により骨は吸收されるとい子れ右が文，その譏棈 は文献的にみても未だ充分飞解明されていない，10年前 までは真珠腫の骨破堎機序を説明する鼠毛有力な説岋压

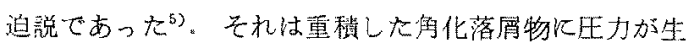

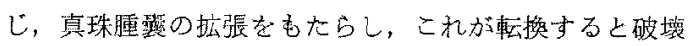
エネルギーとなるという推論に根ざしていた，しかし真

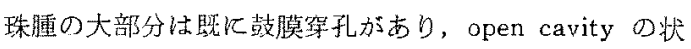

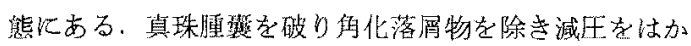
名保存的治療応用例でも骨破墥が進行し聴力が悪化する

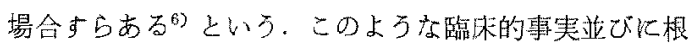
治手術を行った閏放乳笑洞に街前には夕られなかった半

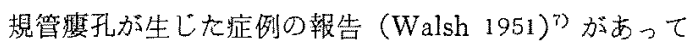
以来，今日飞到るまで稌々飞ではあるが质力説は後退し

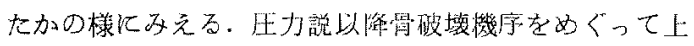

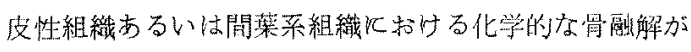

注目されるにいたった

この化学的骨融解の機序をめぐる酵素学的研然は今日 までいくつかの㪕告がある。

慢性中耳资の醉素活性を最初反報告したのは Harris ${ }^{9}$ (1962) であった。彼はアシドフォスファターゼ活性が

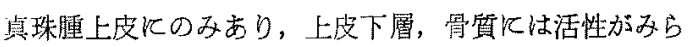
れなかったことより真珠腫上皮が骨破壤の一次的因子で あると若えた。

Palva et al ${ }^{10)}$ (1971) はアシドフォスファターゼ 以外にアミノペブチダーゼ, ラクテート・デハイドロゲ ナーゼやエステラーゼの醏絮活性を調ペ Harris の見解 を支持した，更に真珠腫上皮の增殖エネルギーを皮風腫 瘍のそ礼と対比し上皮説を支持する幾つかの研究があっ た. (Schwarz 1962 ${ }^{11)}$, Morris et al 1957 ${ }^{12)}$, Burstone $\left.1955^{13)}\right)$.

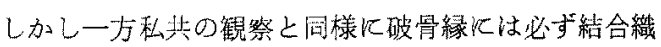

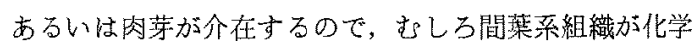
的な骨融解を営む場であると主張する Jaffe (1933) ${ }^{14)}$, Sade $(1974)^{1)}$, Thomsen et al $(1974)^{6)}$, Abramson et al $(1977)^{5)}$, Gantz et al $(1977)^{15)}$ の報告がある.

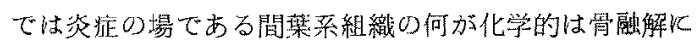
タッチしているのであるうか。

Jaffe $(1933)^{14)}$, Schechter $(1969)^{6)}$ は血管線維堙が

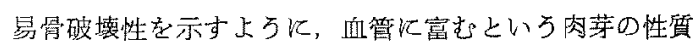

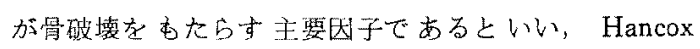
$(1972)^{4}$, Irvig et al $(1970)^{16)}$ は破骨細胞加骨破壊に 関係するという。.Jaffe $(1933)^{142}$, Harris $(1962)^{9)}$ は破

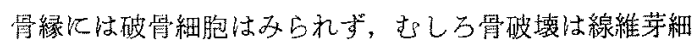
胞の活動飞よるとしている. Thomsen et al $(1974)^{8)}$ は 破䁌細胞は全例にみられるわけでなく，線維芽細胞あ破 骨縁に近接していないが多数の組織球は骨破壇周辺にみ られ，かつアシドフォスファターゼ活性に富导故，組 織球が豪破壊に倠くと述へている。この組織球を破骨細 泡の能駆細胞とみなす意見もある(Hancox 1972

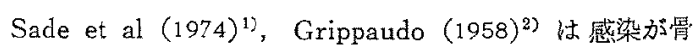

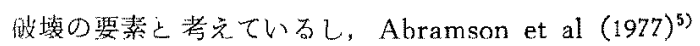
は学光抗体法を用いたヒト皮敖コラゲナーゼ活性の测定 により，コラゲナーゼの細胞局萑を調べ，上皮では基底

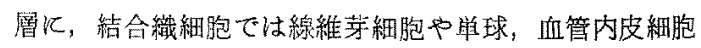
に活性を証明している。

このコラゲナーゼ活性に関しては自血球がコラゲナー

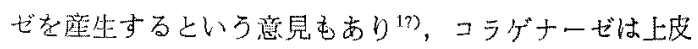

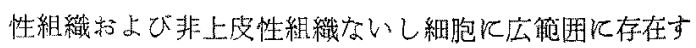


るあのと思われている(永代 1972 ${ }^{18)}$ ). しかしコラゲナ 一ゼが夷際にコラーゲンを溶解する形態的な証明は今ま でのとこらなされてない ${ }^{18)}$

ところで私共の光顕レベルでの組織学的所見からのみ

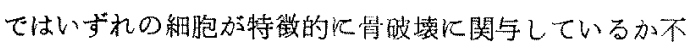
明である・ただし，真珠腫．韭真珠腫を問わず破骨縁に 接する結合䅧には血筸の堌生がみられ，組織球様細胞が 密在していた。そこで現在の病理学上の炎症既念によ

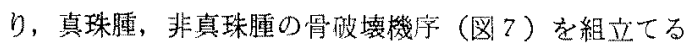

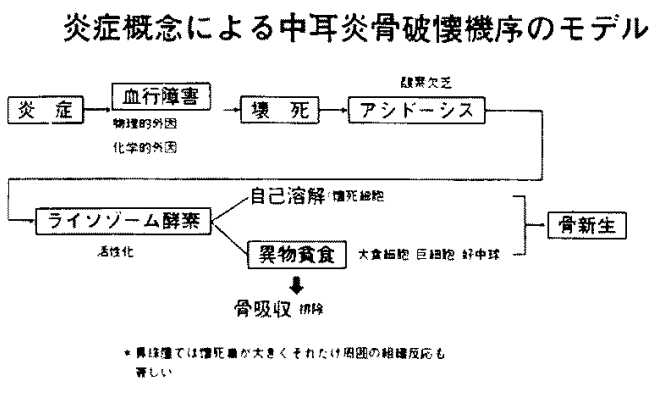

図 7

と，次掟という共通の病態基盤沉むつ真珠腫，非真珠 腫では，まず循環障害がひき金として莇き骨の奏質綳胞

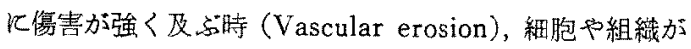
壊死飞陌入り，酸桑不足で酸性となった次淀局所ての化 学的環境の变化があたらされ，紐胞の自己溶解吕局所に 起り，同時に堎死部の踓溶性物質の清墇のため飞活動す る大食細胞(肉芽組織ては組織理が主要な成分)の遊走が 促され，その大食細胞が直接骨吸収にタッチするでする うと考えた。この様に形態的《みられる骨破㯖は組穖球 様細胞による自食, 即ち異物を取り除き修復をもたすす とい弓生物学的防衛反厄の班悲的表現の倳に思われる。

真珠腫で喟破罗が強くみられる理由は，真珠腫では循 環障害を惹起する障恝因子が，前述のことく非真珠湟よ り強烈であって，そのために結果的《は肉芽のあがりも 强く，完全な修復が期待できないまま長期にわたって炎

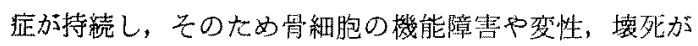

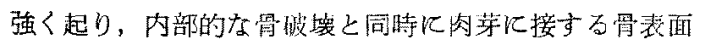

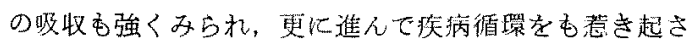
れるためであるう。一」，刺激の弱い非真珠腫では胃吸 取委柽く，それだけ骨吸取について起こる骨新生(再生) が偠勢な状態である様に思われる。

骨はコラーゲン線維や無機絬晶からなる哭機基質と骨 細胞からなるので，骨破壊に際して崿躓的な部分上無

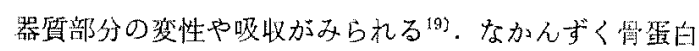

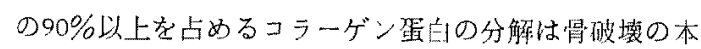
質をつく閏題である。

大食細胞の最も䍕著な機能は活発なライソゾーム段素

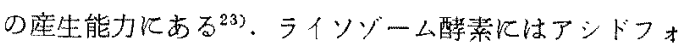
スファターゼ.コラゲナーゼ以外 カテプシン，アシドリポヌタレオ一ゼ、リゾチーよ，工 スデラーゼ，リパーゼなどさまざまな加水分解酵素があ

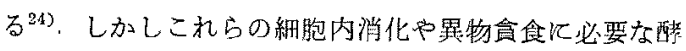
素はすへて集䚚されているわけでなく，良食制激によっ

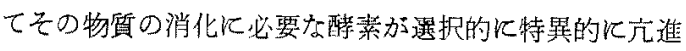
するらしい23

骨の吸取をもたらすといわれるライソゾーム醉素の活 動を怔す機構は末だ不明であるが，ホルモン作用や機械 的な压力，炎症により活性が高まるといわれている それ故真珠腫では炎症座物と思われる角化落滆物の有す る mass としての㙨械的王力, あるい虫中耳资症刺激江 より，ライソゾーム酵菜であるコラゲナ一ゼやアシドフ オスファターゼ活性が高まり，活性を高度に有する大食

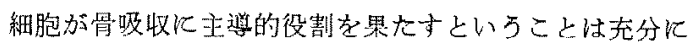
考えられるのである。

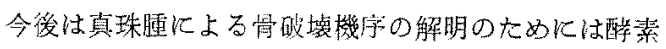
組織化学的な，電子頙徽鏡的な, 電頙組織化学的な, 生 化学的な, 免疫学的な側面加 50研㚾加一段上推谁され る必要があると考えている。

\section{結語}

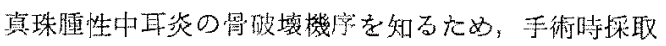
された真珠腫性中耳资考含古 181 耳 0 慢性中耳炎の鼓室 粘膜, 病的耳小骨老臨床的, 組織学的に㓋察し, 次の結 羭老得大。

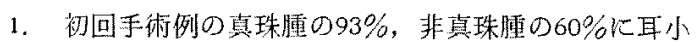

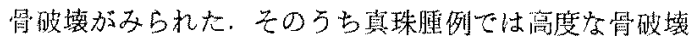
をみるあの多かった。しかし耳小骨欠損の部位比率は 真珠腫，韭真珠腫とも同しで㕷骨に一番多く，炏いで柏 骨, 鐙盈の狛であった。

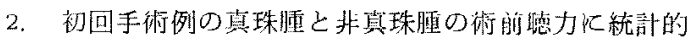
な差翼はなかった。しかし耳小骨破壊度は賞珠腄で侥る

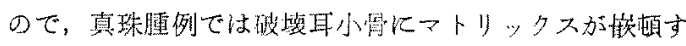

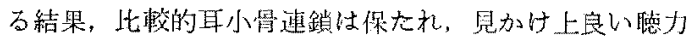
が得られるものと推諭した。

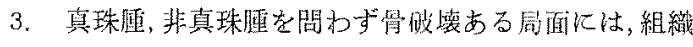

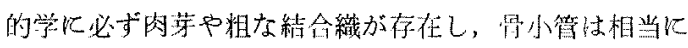




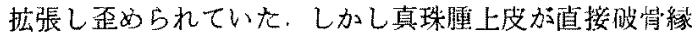
て接しているすのはなかった。

4. 真珠腫之非真珠腫汇みられた組織学上の僅かな差異

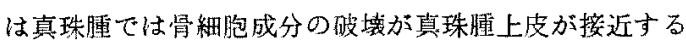
部位の骨表面に目立ち，非真珠腫では骨面が高度に破垻 されたものは少く，反面骨の新生によ西修復が多くみら れた.

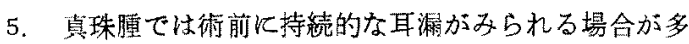
く，化学的療法に抵抗する細菌培地としての性格を有す ると思われた。

6. 破骨縁にみられた肉芽の性状は組織球様細胞を主と した非特異的增殖性慢性㷋症組織のそれで，骨病態と问 様真珠腫と非真珠腫に質的な差異は認められなかった。

7, 真珠堙之非真珠堙の耳小骨破壊の量的な差異は，真 珠腫では何加特别な骨破壊能力があると考元るより，炎 症に上る血行障害をきたす障害因子が強く，その血行障 害がひき金としてはたらき，適当な生化学的条件下で活 動する大食細胞（主に組穖球）の頜食機能が骨吸収に重要 であると考えた：そして骨破壊は現象論的炕は生体防御 機構の形態的表現形として把えられるものと推祭した。

8. 大食細胞の機能はライソゾーム醉素に由来し， ラ1 ソゾーム醏菜であるコラゲナーゼやアシドフォスファ夕 一ゼ活性が一時的飞骨破壤局所で高まることを推論し た. 更に今後骨破壊機序の解明のためには，基質病理学： 特に生化学的側面からの研究が必要であることを强調し た.

\section{考文 献}

1) Sade $I$ and Berco $E$ : Bone destruction in chronic otitis media. A histopatholigical study. J Laryngol Otol, 88: 413-422, 1974.

2) Grippauco $M$ : Histopathological studies of the ossicles in chronic otitis media. J Laryngol Otol 72: 177-189, 1958 .

3) Holti $G$ : The nature and behaviour of the deep netal skin. J Laryngol Otol 77: 122-125, 1963.

4) Hancox $N \quad M$ : Biology of bone-Cambridge University Press, Cambridge, Great Britain, 1972.

5) Abramson $M$ and Huang $C$ : Cholesteatoma and bone resorption. Cholesteatoma: First International Conference. Aesaulapin Publishing Company. Birmingham, Alabama, 162-166, 1977.
6) Schechter G: A review of cholesteatoma pathology. Laryngoscope 79: 1907-1920, 1969.

7) Walsh $T E$, Couell $W P$ and Ogura $J H$ : The effect of cholestatosis on born. Ann Otol Rhinol Laryngol 60: 1100-1113, 1951.

8) Thomsen $J$, Jorgnsen $M B$, Bretlau $P$ and Kristensin $K$ : Bone resorption in chronic otitis media. A histological and ultrastructual study. II. cholesteatoma. J Laryngol Otol 88: 983-992, 1974.

9) Harris $A J$ : Cholesteatoma and chronic otitis media. Laryngoscope 72: 954-980, 1962.

10) Palva T, Palva $A P$ and Samnert $K$ : Middle ear mucosa and chronic ear disease. II. Enzyme studies. Arch Otolaryngol 91: 50-56, 1970.

11) Schwar: M: Pathogenese Mitlleohrcholesteatoms und Jautkrankheiten. Z Laryngol Rhinol Otol 41: 131-140, 1962.

12) Morris $B$ and Nachlas $M M$ : Histochemical study of three dehydrogenase syseims in human tumors. Cancer 12: 1238-1247, 1957.

13) Burstane $M D$ : Histochemical demonstration of proteolytic activity in human neoplasms. J Natl Cancer Inst 16: 1149-1161, 1955.

14) Jaffe $H L$ : Hyperparathyroidism (Recklinghausens disease of bone). Arch. Pathol 16: 6369, July and 236-245, August; 1933.

15) Gants $B Z$ and Abramson $M$ : Decalcification factors in granulation tissue and ear canal skin. Cholesteatoma. First international conference. Aesaulapin Publishing Company. Birmingham. Alabana 167-169, 1977.

16) Irving $J T$ and Heeleym $J D$ : Resorption of bone collagen by multinucleated cells. Calcif. Tissue Res 6: 254-261, 1970.

17）字宿源太郎：资症宩のコシグナーセ慢性炎症と免

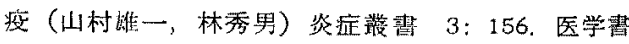
院 東京 1977 .

18）永井 裕：生体内に招けるコラゲナーセ活性につい 乙 日本医師会䧴誌 68: 584, 1972.

19) Vaugham $J M$ : The physiology of bone, Clarendon Press. Oxford, London, 1975.

20) Abramson $M$ : Collagenolytic activity in middle 
ear cholesteatoma. Ann Otol Rhinol Laryngol 78: $112-124,1969$.

21) Abramson $M$ and Gross $J$ : Further studies on a collagenase in middle ear cholesteatoma. Ann Otol Rhinol Laryngol 80: 177-185, 1971.

22）森昌竧，他：口腔粘膜ならびに菌肉用組織疾患に 怙けるアルカリフォスフフターセとアシドフォスフ アターセの組化学的研究，日本口腔科学誌 6 : 239, 1960.

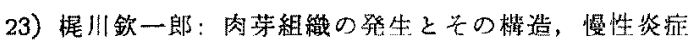

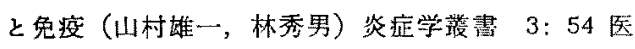
学畫院 東京 1977 .

24) Ruedi $L$ : The pathogenesis and treatment of cholesteatoma in chronic suppuration of the temporal bone. Ann Otol Rhinol Laryngol 66: 283-305, 1957.

52) Vaes $G$ and Jacques $P$ : Studies on bone enzymes.
The assay of acid hydrolases and other enzymes in bone tissue. Biochem. J 97: 380-388, 1965.

26) 金井環, 田中健二, 逞城寺宗知: 病理学, 医学書 院，禁京 1977 .

27）新川秀一，他：真珠腫性中耳炎括上び非具珠腫性中

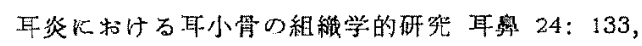
1978.

诚篗するに当り，御校閲御指澊を頂きました本多芳男 教授に梁謝致します。

坛拉本諭交の要旨は第7回日本耳科学会にて発表した。 立た試料作裴に御協力やいただいた福田津子技師に愁 諆の意を裴します。

\section{（原稿受付 昭和53．11，10日）}

別刷請求先 $\bar{T} 105$ 東京都港区西新楿 3-25-8 東京愁患会医科大学耳鼠喁喉科学数室 当䊩 雄一 